\title{
Response of Clarias gariepinus to Allium sativum-based diet on growth performance and Staphylococcus aureus challenge infection
}

\author{
*NWABUEZE, AA; EKELEMU, JK; OWE, OA \\ Department of Fisheries, Delta State University, Asaba Campus, Asaba, Southern Nigeria. \\ *Corresponding Author Email: aanwabueze2@gmail.com; Tel: +2348064138580
}

\begin{abstract}
The response of Clarias gariepinus to Allium sativum on growth performance and as anti-bacterial agent in Staphylococcus aureus challenge infection was evaluated. A. sativum was included at $0 \%$ (control), $1.5 \%$, $3.0 \%$, and $4.5 \%$ in fish diet. Twenty fish samples each were randomly distributed into four tanks (T1, T2, T3 and T4). Fish were fed twice daily at $5 \%$ body weight for twelve weeks. All fish were challenged with $0.5 \mathrm{ml}$ of pure culture of $S$. aureus. A significant $(\mathrm{P}<0.05)$ increase in body weight, total length and standard length was observed. A. sativum at 3.0\% inclusion promoted highest growth with feed conversion ratio (1.25-1.41), protein efficiency ratio (1.72-0.56), specific growth rate (1.92-2.09), condition factor (0.83-1.99) and survival rate (60-95). Fish-fed $A$. sativum diet showed that $4.5 \%$ inclusion had the least $S$. aureus activity. Bacteria load significantly $(\mathrm{P}<0.05)$ decrease at week 12. Culture water had dissolved oxygen of $4.0-4.2 \mathrm{mg} / \mathrm{L}, \mathrm{pH} 6.0-7.0$ and temperature of 26.0$28.0^{\circ} \mathrm{C}$. This study has shown that $A$. sativum supplemented diets enhanced growth of $C$. gariepinus and functioned as antibacterial agent against $S$. aureus. A. sativum at 3.0\% inclusion in diet is recommended for better fish growth and $4.5 \%$ A. sativum for antibacterial action.
\end{abstract}

\section{DOI: $\underline{\text { https://dx.doi.org/10.4314/jasem.v24i5.4 }}$}

Copyright: Copyright $($ C 2020 Nwabueze et al. This is an open access article distributed under the Creative Commons Attribution License (CCL), which permits unrestricted use, distribution, and reproduction in any medium, provided the original work is properly cited.

Dates: Received: 10 March 2020; Revised: 17April 2020; Accepted: 20April 2020

Keywords: Fish, herb, growth, infection

Clarias gariepinus is a dominant freshwater fish and popular in commercial aquaculture due to its ability to grow rapidly and high tolerance to environmental conditions (Mohamed et al., 2017). However, C. gariepinus has been found to be susceptible to both microbial and parasitic infections particularly in intensive culture systems (Sudheesh et al., 2012; Opiyo et al., 2018). For decades antibiotics have been used for the treatment of bacterial infection in fish. The adverse effects associated with the use of antibiotics include drug residue, bioaccumulation and resistance of pathogens, which threaten human consumers (Lee and Gao, 2012). Hence, herbs are now being used as probiotics in preventing bacterial infections and are gaining success because they are cost effective, ecofriendly and have minimal side effects (Carusol et al., 2013). Herbs exhibit anti-microbial, anti-stress, appetite stimulation, immunostimulation, and aphrodisiac and antipathogenic effects which facilitate growth and maturation of cultured species (Harikrishnan et al., 2011). Alluim sativum is a pungent herb and has been reported to inhibits bacterial growth, promote fish growth and enhancement of blood parameters (Nya and Austin, 2009; Dikel, 2015). In aquaculture, A. sativum has been observed to promote growth, enhance immunity, stimulate appetite and strengthens the control of bacteria and fungi pathogens (Harris et al., 2001; Lee and Gao, 2012). S. aureus is one of the major bacterial agents causing food-borne diseases in humans worldwide and has been found on skin of healthy people and animals including fish (Fetsch and Johler, 2018).The response of Clarias gariepinus to $A$. sativum based diet on growth performance and Staphylococcus aureus challenge infection was investigated. 


\section{MATERIALS AND METHODS}

Sampling: One hundred and sixty 6 weeks old fingerlings of $C$. gariepinus with a mean total length of $11.47 \pm 0.24 \mathrm{~cm}$ and a mean body weight of $11.85 \pm$ $0.24 \mathrm{~g}$ were purchased from Ben Fish Farm, in Asaba and transported to Fisheries Laboratory of the Department of Animal Science and Fisheries, Delta
State University, Asaba Campus, for the study which lasted 12 weeks in 2019.

Preparation of A. sativum extracts: A. sativum bulbs obtained locally were washed thoroughly under running tap water and aqueous extract obtained according to Mikail (2010). The phytochemical properties of A. sativum are documented (Charkraborty and Hancz, 2011).

\begin{tabular}{lrrrr}
\multicolumn{5}{c}{ Table 1. Composition of Experimental Diets $(\mathrm{g})$. } \\
\hline Ingredients & $\mathrm{T} 1(0 \%$, Control $)$ & $\mathrm{T} 2(1.5 \%)$ & $\mathrm{T} 3(3 \%)$ & $\mathrm{T} 4(4.5 \%)$ \\
\hline Fish meal & 20.57 & 20.57 & 20.57 & 20.57 \\
Groundnut cake & 20.57 & 20.57 & 20.57 & 20.57 \\
Soya bean meal & 20.57 & 20.57 & 20.57 & 20.57 \\
Yellow maize & 23.30 & 23.30 & 23.30 & 23.30 \\
Vitamin premix & 3.00 & 3.00 & 3.00 & 3.00 \\
Salt & 0.50 & 0.50 & 0.50 & 0.50 \\
Bone meal & 1.00 & 1.00 & 1.00 & 1.00 \\
Vegetable oil & 9.50 & 9.50 & 9.50 & 9.50 \\
Methionine & 0.50 & 0.50 & 0.50 & 0.50 \\
Lysine & 0.50 & 0.50 & 0.50 & 0.50 \\
Garlic & 0.00 & 1.50 & 3.00 & 4.50 \\
\hline
\end{tabular}

\begin{tabular}{|c|c|c|c|c|}
\hline & $\begin{array}{l}\text { T1 }(0 \% \\
\text { Control })\end{array}$ & $\begin{array}{l}\text { T2 } \\
(1.5 \%)\end{array}$ & $\begin{array}{l}\text { T3 } \\
(3.0 \%)\end{array}$ & $\begin{array}{l}\text { T4 } \\
(4.5 \%)\end{array}$ \\
\hline Crude protein $(\%)$ & 30.32 & 32.55 & 34.12 & 35.43 \\
\hline Moisture content $(\%)$ & 8.48 & 7.50 & 7.46 & 5.12 \\
\hline Ash content $(\%)$ & 2.48 & 2.97 & 2.99 & 3.01 \\
\hline Crude fiber $(\%)$ & 3.47 & 4.21 & 4.94 & 5.01 \\
\hline Nitrogen free Extract (NFE) & 55.31 & 53.00 & 51.04 & 51.87 \\
\hline
\end{tabular}

Acclimation and Experimentation: Fish specimens were acclimated for 14 days in a stock tank $(45 \mathrm{~cm} \mathrm{x}$ $45 \mathrm{~cm} \mathrm{x} 90 \mathrm{~cm}$ ) containing $120 \mathrm{~L}$ of bole hole water. Fish were fed commercially available fish feed at 5\% body weight twice daily. Stock tank was well aerated and water temperature maintained at a ranged of 27.0 ${ }^{0} \mathrm{C}-28.0{ }^{0} \mathrm{C}$. Twenty experimental fish each were randomly distributed into four tanks, $\mathrm{T} 1$ as control $(0 \%)$ and T2 (1.5\%), T3 (3.0\%) and T4 (4.5\%) as treatments dietary inclusion of $A$. sativum. The experiments were in duplicates and maintained in a weekly half renewal static bioassay. Experimental diets (Table 1) were formulated according to Ndong and Fall (2011). Prior to administration of experimental diet, fish were starved for 24 hours. Experimental diets were analyzed (AOAC, 1984) and proximate composition as presented in Table 2.

Growth Parameters and Nutrients Utilization: Growth parameters were calculated following the method described by Bagenal (1978). Growth indices considered were percentage weight gain and total length gain, specific growth rate (SGR), feed conversion ratio (FCR), protein efficiency ratio (PER), condition factor, $\mathrm{K}$ and survival rate, $\mathrm{SR}$.

$$
S R G=100\left[\frac{\log W_{f}-\log W_{i}}{T}\right]
$$

Where $\mathrm{W}_{\mathrm{f}}=$ final weight, $\mathrm{W}_{\mathrm{i}}=$ initial weight; $\mathrm{T}=$ Time (days)

$$
F C R=\frac{T_{f}}{W_{g}}
$$

Where $\mathrm{T}_{\mathrm{f}}=$ Total feed $(\mathrm{g}) ; \mathrm{W}_{\mathrm{g}}=$ Weight gain $(\mathrm{g})$

$$
\begin{gathered}
K=100 \frac{W}{L^{3}} \\
P E R=\frac{W_{g}}{P_{i}}
\end{gathered}
$$

Where $P_{i}=$ Protein intake $(\mathrm{g})$

$$
S R=100\left[\frac{F S_{i}-M}{F_{i}}\right]
$$

Where $\mathrm{FS}_{\mathrm{i}}=$ initial number of fish stocked; $\mathrm{M}=$ mortality; $F_{i}=$ Initial number of fish

Bacterial Studies: Bacterial isolates were obtained from diseased C. gariepinus (Plate1 a, b \& c) collected from Obinna Farms in Ugbolu, Delta State. Isolates were obtained by macerating aseptically $1 \mathrm{~cm}$ of skin of the diseased fish. Nutrient and MacConkey agar 
media used were prepared according to the manufacturer's instruction. $S$. aureus isolates were cultured and sub-cultured to obtain pure cultures. Stock culture of the isolates were prepared by making slants of nutrients agar in Mac-Cartney bottles for modulation of pure distinct colonies. Serial dilution was made to achieve $10^{-9}$ dilution factor. All culture water: T1, T2, T3 and T4 were infected with $0.5 \mathrm{ml}$ respectively.

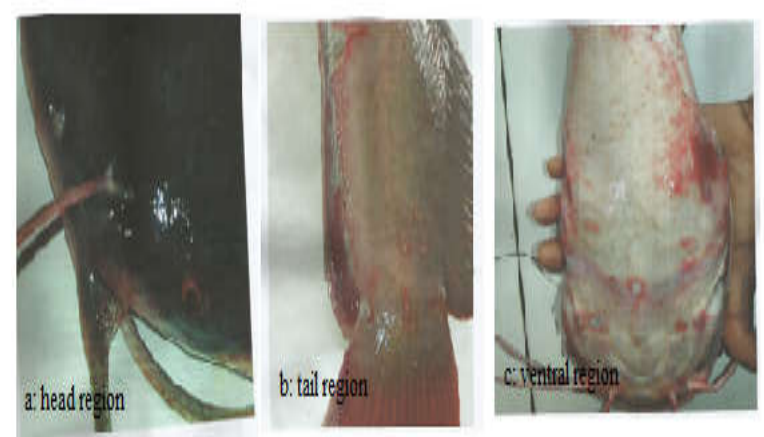

Plate1 a, b, c : Diseased Clarias garipienus with Staphylococcus aureus obtained from Obinna farm, Ugbolu Delta State

Gram Staining and biochemical characterization were done according to Olutiola et al. (1991).The isolates were identified by comparing their characteristics with those of known taxa, as described by Oyeleke and Manga (2008). Experimental fish were sampled biweekly for a period of six months for bacterial examination for possible infection. The average count on plates was multiplied by dilution factor and expressed as colony forming unit per milliliter (Cfug$\left.{ }^{3}\right)$ of the original factor. Water quality parameters such as temperature, dissolved oxygen, hydrogen ion concentrations, $\mathrm{pH}$ and ammonia were analyzed according to (ALPHA, 2010).

Data Analysis: Data collected were subjected to one way analysis of variance with significant means $(p<0.05)$ separated using Duncan's Multiple Range Test.

\section{RESULTS AND DISCUSSION}

Mean growth in body weight, standard length and total length were progressive during the experimental period (Figure 1).

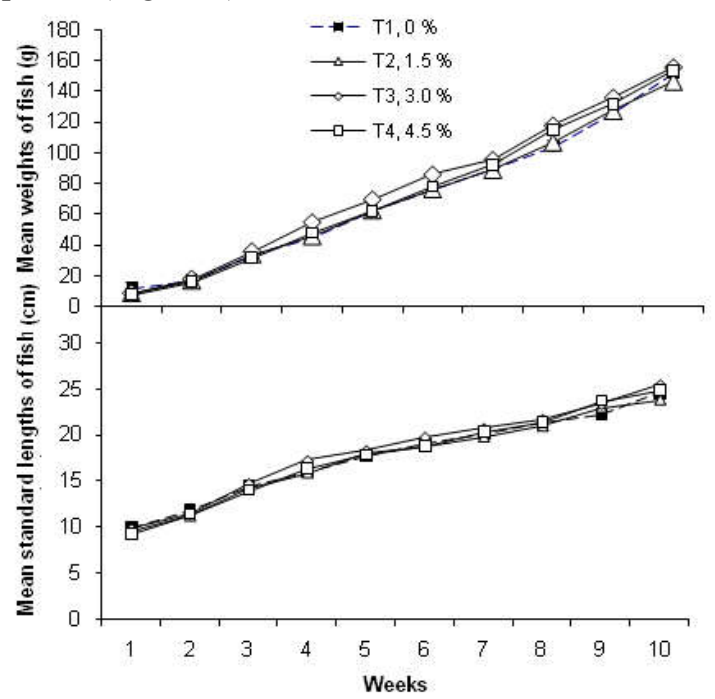

Fig 1. Weekly mean weight and standard length of $C$. gariepinusfed different dietary inclusion of $A$. sativum

Table 3. Nutrient utilization of C. gariepinus-fed dietary inclusions of $A$. sativum

\begin{tabular}{lllll}
\hline Parameters & T1 $(0 \%)$ & T2 $(1.5 \%)$ & T3 $(3.0 \%)$ & T4 $(4.5 \%)$ \\
\hline Feed conversion ratio, FCR & 1.35 & 1.41 & 1.25 & 1.30 \\
Protein efficiency ratio, PER & 1.49 & 1.52 & 1.73 & 1.69 \\
Protein intake & 14.2 & 16.9 & 18.6 & 17.5 \\
Specific growth rate, SGR & 1.95 & 1.92 & 2.06 & 1.99 \\
Condition factor, K & 0.83 & 1.91 & 1.99 & 1.85 \\
Survival rate. \% & 60 & 70 & 80 & 95 \\
\hline
\end{tabular}

Table 4. Biweekly mean of Staphylococcus aureus load (cfu/g) of C.gariepinus-fed dietary inclusion of $A$. sativum.

\begin{tabular}{llrrr}
\hline Weeks & TI $(0 \%)$ & \multicolumn{1}{c}{ T2 $(1.5 \%)$} & \multicolumn{1}{c}{ T3 $(3.0 \%)$} & \multicolumn{1}{c}{ T4 $(4.5 \%)$} \\
\hline Week 2 & $127.50 \pm 2.50^{\mathrm{c}}$ & $112.50 \pm 1.50^{\mathrm{c}}$ & $112.50 \pm 2.50^{\mathrm{b}}$ & $99.50 \pm 0.50^{\mathrm{a}}$ \\
Week 4 & $131.50 \pm 1.50^{\mathrm{d}}$ & $86.00 \pm 1.00^{\mathrm{c}}$ & $77.70 \pm 1.00^{\mathrm{b}}$ & $69.50 \pm 0.50^{\mathrm{a}}$ \\
Week 6 & $144.00 \pm 1.00^{\mathrm{c}}$ & $73.00 \pm 3.00^{\mathrm{b}}$ & $69.00 \pm 2.00^{\mathrm{b}}$ & $58.00 \pm 1.00^{\mathrm{a}}$ \\
Week 8 & $152.00 \pm 3.00^{\mathrm{c}}$ & $57.50 \pm 2.50^{\mathrm{b}}$ & $47.50 \pm 0.50^{\mathrm{a}}$ & $43.50 \pm 1.50^{\mathrm{a}}$ \\
Week 10 & $156.00 \pm 2.00^{\mathrm{c}}$ & $50.00 \pm 3.00^{\mathrm{b}}$ & $36.50 \pm 2.50^{\mathrm{a}}$ & $30.50 \pm 1.50^{\mathrm{a}}$ \\
Week 12 & $174.50 \pm 4.50^{\mathrm{c}}$ & $45.00 \pm 4.00^{\mathrm{b}}$ & $33.50 \pm 2.50^{\mathrm{ab}}$ & $26.50 \pm 1.50^{\mathrm{a}}$ \\
Means on the same row with the same superscript are not significantly different $(P>0.05)$
\end{tabular}

This study shows that fish fed $(3.0 \%)$ of $A$. sativum inclusion in diet had the highest specific growth rate.This finding is in agreement with the study of Javadzadeh et al., (2012) who observed high specific growth rate in L. vannami when fed Artemia nauplii enriched with $200 \mathrm{mg}$ garlic extract/ L. Jasour et al.,
(2018) reported that biogenic diet increased feed intake, feed conversion ratio (FCR) and PER in fish which could have attributed to the better growth performance observed in fish fed $3.0 \%$ of garlic. PER and FCR are utilized as quality indicators for fish diet and its amino acid balance. Therefore, these factors are used to evaluate protein utilization and turnover (Shalaby et al., 2006). Table 3 shows the nutrient 
utilization of $C$. gariepinus-fed dietary inclusions of $A$. sativum. The biweekly mean bacteria load of fingerlings of $C$. gariepinus-fed dietary inclusion of $A$. sativum is presented in Table 4.This study revealed a significant decrease $(\mathrm{P}<0.05)$ of bacteria load of $C$. gariepinus-fed experimental diet. This finding is in line with the report of Rahman et al. (2008) who found that young Thai silver barb, Barbonymus gonionotus fed a diet supplemented with $8 \mathrm{mg} \mathrm{mL}^{-1}$ garlic showed the best recovery rate $(90 \%)$ during the 10 -days experimental period. Deresse (2010) reported that dilute solutions of garlic completely inhibited the growth of $S$. aureus at concentrations greater than 7.50 $\mathrm{mg} \mathrm{mL} \mathrm{m}^{-1}$. C. gariepinus in treatment tanks, were positively infected with $S$. aureus. However, $4.5 \%$ garlic inclusion was observed to be more effective in reducing $S$. aureus counts/loads. Aly and Mohamed (2010) found that O. niloticus-fed 3\% garlic supplemented feed showed a significantly increased survival rate $(85 \%)$ even after infection with $A$. hydrophila. The water quality parameters were within the levels recommended for fish culture (Boyd and Lichtkoppler, 1990).

Conclusion: This study has shown that garlic supplemented diets in fish enhanced growth performance and reduced bacterial load in Clarias gariepinus. Three percent $(3.0 \%)$ inclusion of garlic in diet is recommended for increase in fish growth performance while $4.5 \%$ garlic inclusion can be used to reduce Staphylococcus aureus counts/loads in Clarias gariepinus fish culture.

\section{REFERENCES}

ALPHA (2010).Standard methods for the examination of water and wastewater, $20^{\text {th }}$ edition.American public health association, Washington D.C.

Aly, SM; Mohamed, MF (2010). Echinacea purpurea and Allium satium as immunostimulant in fish culture using Nile Tilapia (Oreochomis niloticus) J. An. Physio. An. Nutri. 94:31-39.

AOAC (Association of official Analytical chemists) (1984) in Neirch, K. (ED). Official methods of analysis of the AOAC, $\left(14^{\text {th }}\right.$ ed $)$ AOAC, Arlington, VA, USA.

Bagenel, TB (1978).Methods of assessment of fish production in freshwater. Blackwell science publication oxford IBP Handbook No 3, 35pp.

Boyd, CE; Lichtkoppler, F (1990).Water quality in pond for aquaculture Alabama Agricultural. Experimental Station Auburn University. Alabama; Pp 30.
Caruso, D; Lusiastuti, AM; Taukhid, Slenbrouk, J; Komarudin, O; Legendre, M (2013). Traditional pharmacopeia in small scale freshwater fish farms in west java, Indonesia: an ethnoveterinary approach, Aquaculture. 416-417, 334-345.

Chakraborty, SB; Hancz, C (2011).Application of phytochemicals as immunostimutant antipathogenic and antistress agents in fin-fish culture. Rev. Aquaculture. 3, 103-119.

Deresse, D (2010). Antibacterial effect of garlic (Allium sativum) on Staphylococcus aureus: an in vitro study. Asian J. Med. Sci. 2:62-65.

Dikel, S (2015). The use of garlic (Allium sativum) as a growth promoter in Aquaculture. Turk. J. Agric. 3 (7):529-536

Fetsch, A; Johler, S (2018). Staphylococcus aureus as a food borne pathogen. Current Clinical Microbiology Reports, Springer International Publishing. doi.10.1007/s40588-018-0094-X

Hariskrishan, R; Kim, JS; Balasundaram, C; Heoms (2011). Protective effect of herbal and probiotics enriched diet on haematological and immunity status of Oplegnathus fasciatus (Temminck and Schelegel) against Edwardsiella tarda. Fish shellfish Immunol. 30; 886-893.

Harris, JC; Cottrell, SL; Plummer, S; Lloyd, D (2001).Antimicrobial Properties of Allium sativum (garlic). Appl. Microbiol. Biotechnol. 57: 282-286.

Jasour, M; Wagner, L; Sundekilde, U; Larsen, B; Rasmussen, H; Hjermitslev, NH; Hammershoj, M; Dalsgaard, A; Dalsgaard, T (2018). Fishmeal with Different Levels of Biogenic Amines in Aquafeed: Comparison of Feed Protein Quality, Fish Growth Performance, and metabolism. Aquaculture 488:80-89.

Javadzadeh, M; Salarzadeh, AR; Yahyavi, M; Hafezieh, M; Darvishpour, H (2012). Effect of garlic extract on growth and survival rate in Litopenaeus vannami post larval .Iranian Sci. Fisheries J. 21 (1): 39-46.

Lee, J; Gao, Y (2012). Review of the application of Garlic, Allium sativum, in aquaculture. J. World Aquaculture. Soc. 43 (4): 447-459

Mikail, HG (2010). Phytochemical screening, elemental analysis and acute toxicity of aqueous 
extract of Allium sativum L. bulbs in experimental rabbits. J. Med. Plants Res. 4(4): 322-326.

Mohamed, MME; Essa, MA; Osman, AGM; Shalaby, SM; Moustafa, AM (2017). Growth performance of African catfish, Clarias gariepinus (Burchell, 1822) treated with live baker's yeast (Saccharomyces cerevisiae) in Egypt. Inter. J. Biotechnol. Bioeng. 3 (6): 171-182.

Ndong, D; Fall, J (2011). The effect of garlic (Allium sativum) on growth and immune responses of hybrid tilapia (Oreochromis niloticus $\mathrm{x}$ Oreochromis aureus). J. Clinic.Immnunol. Immunopathol. Res. 3 (1): 1-9.

Nya EJ; Austin, B (2009).Use of garlic, Allium sativum, to control Aeromonas hydrophila infection in Rainbow trout, Oncorhynchus mykiss (Walbaum).Journal of Fish Diseases, 32(11): 963-970.

Olutiola PO; Fammurewa O; Sonntag, HG (1991). An introduction to general microbiology. A practical approach. $1^{\text {st }}$ edition. Heidelberger verlugsanstalt and Drukerei GMB Herdelberger, 267.
Opiyo, MA; Marijani, E; Muendo, P; Odede, R; Leschen, W; Charo-Karisa, H (2018). A review of aquaculture production and health management practices of farmed fish in Kenya. Inter. J Vet. Sci. Medic. 6(2): 141-148

Oyeleke, SB; Manga SB (2008).Essential laboratory practicals in Microbiology. Tobest publisher, Minna Nigeria, 36-75.

Rahman, TM; Akanda MR; Rahman, MM (2008). Evaluation of the efficacies of selected antibiotics and medicinal plants on common bacterial in fish pathogens. J. Bangladesh Agric.Univ. 7(1):163168.

Shalaby, AM;Khattab, YM; Abdel Rahman, AM (2006). Effects of garlic (Allium sativum) and chloramphenicol on growth performance, physiological parameters and survival of Nile Tilapia (Oreochromis niloticus). J. Venomous. Animals and Toxins including Tropical Diseases, 12(2): 172-201.

Sudheesh, PS;Al-Ghabshi, A; Al-Mazrooei, N; AlHabsi, S (2012. Comparative Pathogenomics of Bacteria causing infectious diseasesin fish. Inter. J. Evolut. Biol. 2012.doi: 10.1155/2012/457264 